\title{
The Binding of 2-(4'-Methylaminophenyl)Benzothiazole to Postmortem Brain Homogenates Is Dominated by the Amyloid Component
}

\author{
William E. Klunk, ${ }^{1}$ Yanming Wang, ${ }^{2}$ Guo-feng Huang, ${ }^{2}$ Manik L. Debnath, ${ }^{1}$ Daniel P. Holt, ${ }^{2}$ Li Shao, ${ }^{1}$ \\ Ronald L. Hamilton, ${ }^{3}$ Milos D. Ikonomovic, ${ }^{4}$ Steven T. DeKosky, ${ }^{4}$ and Chester A. Mathis ${ }^{2}$ \\ ${ }^{1}$ Laboratory of Molecular Neuropharmacology, Department of Psychiatry, Western Psychiatric Institute and Clinic, ${ }^{2}$ PET Facility, Department of Radiology, \\ ${ }^{3}$ Division of Neuropathology, Department of Pathology, and ${ }^{4}$ Department of Neurology, University of Pittsburgh Medical Center, Pittsburgh, Pennsylvania \\ 15213
}

2-(4'-Methylaminophenyl)benzothiazole (BTA-1) is an uncharged derivative of thioflavin-T that has high affinity for A $\beta$ fibrils and shows very good brain entry and clearance. In this study, we asked whether BTA-1, at concentrations typical of those achieved during positron emission tomography (PET) studies, could specifically bind to amyloid deposits in the complex milieu of human brain or whether amyloid binding was overshadowed by nonspecific binding, found even in brains that did not contain amyloid deposits. We quantitatively assessed $\left[{ }^{3} \mathrm{H}\right] \mathrm{BTA}-1$ binding to crude homogenates of postmortem brain obtained from nine Alzheimer's disease (AD) subjects, eight controls, and six subjects with non-AD dementia. BTA-1 binding was $>10$-fold higher in AD brain, and the majority (94\%) of the binding was specific (displaceable). High-affinity $\left[{ }^{3} \mathrm{H}\right] \mathrm{BTA}-1$ was observed only in AD brain gray matter and was not present in control brain gray matter, AD brain white matter, or cerebellum. The $K_{\mathrm{d}}$ of $\left[{ }^{3} \mathrm{H}\right] \mathrm{BTA}-1$ for binding to AD brain $(5.8 \pm 0.90 \mathrm{nM})$ was very similar to the $K_{\mathrm{d}}$ for binding to synthetic $\mathrm{A} \beta$ fibrils. In addition, the $K_{\mathrm{i}}$ of various BTA analogs for inhibition of [ $\left.{ }^{3} \mathrm{H}\right] \mathrm{BTA}-1$ binding to AD brain homogenates was very similar to their $K_{\mathrm{i}}$ for inhibition of $\left[{ }^{3} \mathrm{H}\right] \mathrm{BTA}-1$ binding to synthetic A $\beta$ fibrils. Nanomolar concentrations of $\left[{ }^{3} \mathrm{H}\right] \mathrm{BTA}-1$ did not appear to bind to neurofibrillary tangles. Finally, BTA-1 did not appear to bind significantly to common neuroreceptors or transporter sites. These data suggest that the binding of BTA- 1 to AD brain is dominated by a specific interaction with A $\beta$ amyloid deposits.

Key words: Alzheimer's disease; neuroimaging; plaques; neurofibrillary tangles; positron emission tomography; PET; thioflavin-T; benzothiazole; postmortem; binding

\section{Introduction}

Alzheimer's disease (AD) is defined pathologically by the characteristic deposits found in the brain (Mirra et al., 1991), including amyloid plaques and neurofibrillary tangles (NFTs). Both the amyloid- $\beta(\mathrm{A} \beta)$ protein found in plaques and the tau protein found in NFTs have a predominantly $\beta$-sheet structure (Kirschner et al., 1986). Current evidence suggests that both $\mathrm{A} \beta$ and tau deposits play important roles in the pathophysiological cascade of AD (Goate et al., 1991; Mullan et al., 1992; Hardy et al., 1998; Goedert and Spillantini, 2000; Golde et al., 2000).

$\mathrm{A} \beta$ deposition has become an important therapeutic target in AD research (Schenk et al., 1999; Bard et al., 2000; DeMattos et al., 2001; Olson et al., 2001). Although promising anti-amyloid therapies are being intensely pursued, there is currently no ac-

Received 0ct. 3, 2002; revised Nov. 26, 2002; accepted Jan. 8, 2003.

This work was supported in part by the Alzheimer's Association (Grants IIRG-95-076 and TLL-01-3381 to W.E.K. and NIRG-00-2335 to Y.W.), the National Institutes of Health (Grants AG01039 and AG20226 to W.E.K., AG18402 to C.A.M., and AG05133 to S.T.D.), and Institute for the Study of Aging/American Federation of Aging Research (Y.W.), We thank Dr. Bryan Roth (Case Western Reserve University) and Dr. Linda Brady [National Institute of Mental Health (NIMH)] for allowing us access to the NIMH Psychoactive Drug Screening Program. We thank Dr. Robert Sweet for his help in procuring the appropriate tissue samples and the families that made brain tissue available to the University of Pittsburgh Alzheimer Disease Research Center Brain Bank.

Correspondence should be addressed to Dr. William E. Klunk, University of Pittsburgh, 705 Parran Hall- GSPH, 130 DeSoto Street, Pittsburgh, PA 15213. E-mail: klunkwe@msx.upmc.edu.

Copyright $\odot 2003$ Society for Neuroscience $\quad 0270-6474 / 03 / 232086-07 \$ 15.00 / 0$ cepted tool to directly assess their success in delaying or reversing amyloid deposition in humans. It will be critical to show that a clinical treatment effectively reduces plaque load, before positive or negative effects on clinical cognitive measures can be accurately interpreted. In addition, because the clinical effectiveness of these anti-amyloid therapies will serve as a test of the "amyloid hypothesis" of AD (Hardy and Allsop, 1991; Hardy, 1992), it also will be critical to show that the treatments actually decrease amyloid load before we can make inferences about the validity of the amyloid hypothesis.

Our laboratory has been interested in the development of a noninvasive method for direct and quantitative assessment of amyloid deposition in living subjects (Klunk et al., 1994; Klunk, 1998). We have reported the potential of lipophilic thioflavin-T analogs as amyloid imaging agents (Klunk et al., 2001) and have described a particularly promising carbon-11-labeled derivative of thioflavin- $\mathrm{T}$, namely 2-(4'-methylaminophenyl)benzothiazole (BTA-1) (see Fig. 1) (Mathis et al., 2002). BTA-1 shows very good brain entry and clearance and has been used for in vivo imaging of amyloid deposits in living presenilin-1/amyloid precursor protein transgenic mice using multiphoton microscopy (Mathis et al., 2002). These properties justified further pursuit of BTA-1 as an in vivo human amyloidimaging agent for positron emission tomography (PET).

A critical issue in the development of a PET imaging agent is 
whether binding to brain tissue is dominated by the specific target (in this case, amyloid deposits) or by nonspecific, background binding. Here, we further assessed the utility of BTA-1 for in vivo PET imaging studies by quantitatively assessing its binding to homogenates of postmortem brain from nine AD subjects, eight controls, and six subjects with non-AD dementia (NAD). We found that BTA-1 binding was much higher in amyloidcontaining areas of AD brain tissue, and most of the binding appeared to be specific. In addition, the $K_{\mathrm{i}}$ of various BTA analogs for inhibition of $\left[{ }^{3} \mathrm{H}\right] \mathrm{BTA}-1$ binding to AD brain homogenates was very similar to their $K_{\mathrm{i}}$ for inhibition of $\left[{ }^{3} \mathrm{H}\right] \mathrm{BTA}-1$ binding to synthetic $A \beta$ fibrils. These data suggest that the binding of BTA-1 to AD brain is dominated by specific interaction with amyloid deposits and strengthen the case for use of BTA-1 as an in vivo imaging agent for $\mathrm{AD}$ diagnosis and treatment assessment.

\section{Materials and Methods}

Chemicals. Chemicals were obtained from Sigma (St. Louis, MO) unless noted otherwise. Tritium-labeled and unlabeled BTA-1, and BTA-1 derivatives, were synthesized and characterized as described previously (Klunk et al., 2001; Mathis et al., 2002).

Postmortem tissue. Autopsy tissue was obtained from the University of Pittsburgh Alzheimer Disease Research Center Brain Bank. Clinical and postmortem diagnoses were made by standardized procedures as described previously in detail (Lopez et al., 2000). Clinical characteristics are shown in Table 1.

All nine AD brains represented fairly advanced stages of pathology as is typical of postmortem tissue. The eight control and six NAD brains were selected for having no significant evidence of neuritic plaques or cerebrovascular amyloid. In addition, there were no NFTs in the frontal cortex of any control or NAD case. Samples of medial-frontal cortex gray matter, medial-frontal cortex white matter, entorhinal cortex (EC), or cerebellum were dissected at autopsy from 1-cm-thick coronal slices and frozen at $-80^{\circ} \mathrm{C}$. The tissue was homogenized with a Polytron tissue homogenizer (PT 10/35; Brinkman Instruments, Westbury, NY) at room temperature for $30 \mathrm{sec}$ at setting 6 in $\mathrm{PBS}(137 \mathrm{~mm} \mathrm{NaCl}, 3 \mathrm{~mm} \mathrm{KCl}, 10 \mathrm{~mm}$ sodium phosphate, $\mathrm{pH} 7.0$ ) at a concentration of $10 \mathrm{mg}$ of brain per milliliter. The homogenates were aliquoted and frozen at $-80^{\circ} \mathrm{C}$ until used for binding assays within 2 months. No significant changes in binding characteristics were observed in samples assayed repeatedly over this time period.

Neuroreceptor screening. Binding assays for receptors and transporters were performed as described previously using the resources of the $\mathrm{Na}$ tional Institute of Mental Health Psychoactive Drug Screening Program (Roth et al., 2000, 2001).

Binding studies. $\mathrm{A} \beta(1-40)$ fibrils were prepared, and $K_{\mathrm{i}}$ determinations were performed as described previously (Klunk et al., 2001) using [N-methyl- $\left.{ }^{3} \mathrm{H}\right]$ BTA-1 $\left(\left[{ }^{3} \mathrm{H}\right] \mathrm{BTA}-1 ; 61 \mathrm{Ci} / \mathrm{mmol}\right)$ as the radioligand (Mathis et al., 2002). Binding to brain homogenates for determination of $K_{\mathrm{i}}$ and $K_{\mathrm{d}}$ was performed with slight modifications. Briefly, $10 \mathrm{mg} / \mathrm{ml}$ frozen brain aliquots were thawed and diluted 10 -fold in PBS to $1 \mathrm{mg} / \mathrm{ml}$. Unlabeled test compounds were dissolved in DMSO at $400 \mu \mathrm{M}$ (to yield $<1 \%$ DMSO in the final assay). The appropriate concentrations of unlabeled test compounds were combined with $\left[{ }^{3} \mathrm{H}\right] \mathrm{BTA}-1(\sim 1.2 \mathrm{nM})$ in a volume of $900 \mu \mathrm{l}$ of PBS, pH 7.0. The assay was begun by addition of 100 $\mu l$ of the $1 \mathrm{mg} / \mathrm{ml}$ brain homogenate to achieve a final concentration of $100 \mu \mathrm{g}$ tissue per milliliter. After incubation for $60 \mathrm{~min}$ at room temperature, the binding mixture was filtered through a Whatman GF/B glass filter via a Brandel M-24R cell harvester (Gaithersburg, $\mathrm{MD}$ ) and rapidly washed five times with $3 \mathrm{ml}$ PBS. The filters were counted in Cytoscint-ES after thorough vortexing and sitting overnight. Complete $(100 \%)$ inhibition of specific binding was defined as the number of counts displaced by $3 \mu \mathrm{M}$ unlabeled BTA-1. All assays were performed at least in triplicate. For determination of $K_{\mathrm{i}}$ values, inhibition curves were fit (using the RS/1 statistical package, version 6.1; Brooks Automation, Chelmsford, MA) to the following equation, which is derived from the Hill equation (Bennett and Yamamura, 1985): $\left(\mathrm{F}(\mathrm{x})=M\left(K_{\mathrm{i}}\right)^{\mathrm{H}} /\left\{[L]^{\mathrm{H}}+\right.\right.$

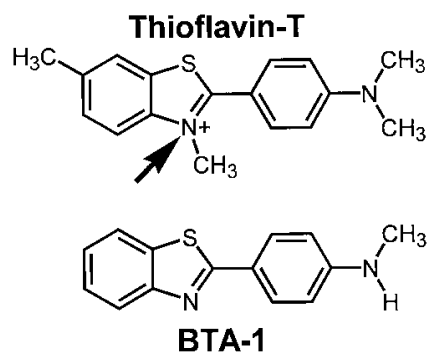

Figure 1. Chemical structures of thioflavin-T and BTA-1. The uncharged compound, BTA-1, differs from thioflavin-T by the lack of three methyl groups, including the methyl group imparting the positive charge to the quaternary heterocyclic nitrogen of thioflavin-T (arrow).

$\left.\left(K_{\mathrm{i}}\right)^{\mathrm{H}}\right\}$, where $M=$ maximal percentage $\left[{ }^{3} \mathrm{H}\right] \mathrm{BTA}-1$ bound (typical fit gave $100-104 \%$ for $M), H$ is the Hill coefficient (typically $0.85-1.0$ ), and $[L]$ is the concentration of inhibitor compound. The $K_{\mathrm{d}}$ value for BTA-1 binding to $A \beta(1-40)$ fibrils and brain homogenates was determined similarly using increasing concentrations of $\left[{ }^{3} \mathrm{H}\right]$ BTA- 1 between 0.2 and $1.2 \mathrm{nM}$, and, for BTA-1 concentrations from $1.2 \mathrm{~nm}$ to $1000 \mathrm{nM}$, a constant concentration of [ $\left.{ }^{3} \mathrm{H}\right]$ BTA-1 (1.2 nM) plus additional unlabeled BTA-1. For comparison of [ $\left.{ }^{3} \mathrm{H}\right] \mathrm{BTA}-1$ binding to brain homogenates among the three groups (AD, control, and NAD), $1.2 \mathrm{~nm}\left[{ }^{3} \mathrm{H}\right] \mathrm{BTA}-1$ was incubated with $100 \mu \mathrm{g}$ tissue in $1 \mathrm{ml}$ PBS with and without $3 \mu \mathrm{m}$ unlabeled BTA-1 as described above. Results were corrected for nonspecific, nondisplaceable binding in the presence of $3 \mu \mathrm{M}$ BTA- 1 and expressed as picomoles of $\left[{ }^{3} \mathrm{H}\right] \mathrm{BTA}-1$ bound per milligram of wet tissue weight in the homogenate. Linearity of $\left[{ }^{3} \mathrm{H}\right] \mathrm{BTA}-1$ binding was determined using $1.2 \mathrm{~nm}$ $\left[{ }^{3} \mathrm{H}\right] \mathrm{BTA}-1$ and $20-500 \mu \mathrm{g} / \mathrm{ml}$ of the AD brain homogenate with the highest level of $\left[{ }^{3} \mathrm{H}\right] \mathrm{BTA}-1$ binding. Likewise, linearity with respect to $\left[{ }^{3} \mathrm{H}\right.$ ]BTA-1 was determined using $100 \mu \mathrm{g}$ of tissue per milliliter and 1.2-6 nM [ $\left.{ }^{3} \mathrm{H}\right] \mathrm{BTA}-1$. Binding results between AD and control and $\mathrm{AD}$ and $\mathrm{NAD}$ were compared using an unpaired sample, unequal variance $t$ test.

Tissue staining. Postmortem tissue from three of the autopsyconfirmed $\mathrm{AD}$ cases used for the binding study was obtained through the University of Pittsburgh Alzheimer Disease Research Center. Samples of medial-frontal cortex, entorhinal cortex, or cerebellum were dissected from 1-cm-thick coronal slices and placed into 10\% buffered formalin (7 d). Paraffin blocks were prepared by sequential dehydration in graded alcohol and vacuum infiltrated in paraffin before embedding and serial sectioning at a thickness of $8 \mu \mathrm{m}$. Tissue was processed for staining, and quenching of autofluorescence was accomplished according to previously described methods (Styren et al., 2000). Quenched tissue sections were taken from PBS into a solution of 100 nм BTA-1 in PBS, pH 7.0, for $45 \mathrm{~min}$. The sections were then dipped into water for $\sim 5 \mathrm{sec}$ before coverslipping with Fluoromount-G (Electron Microscopy Sciences, Fort Washington, PA). Fluorescent sections were viewed using an Olympus Vanox AH-RFL-LB fluorescence microscope using a UV filter set: Ufilter (excites 360-370 nm, dichroic mirror DM400, $420 \mathrm{~nm}$ long-pass filter). X-34 staining was performed according to previously described methods (Styren et al., 2000). X-34-stained tissue sections were optimally viewed with a violet filter set: $\mathrm{V}$-filter (excites $<460 \mathrm{~nm}$, DM455 mirror, $455 \mathrm{~nm}$ long-pass filter).

\section{Results}

Paraffin sections $(8 \mu \mathrm{m})$ from the frontal and entorhinal cortex of AD brain were stained with 100 nM BTA-1 (Figs. 1, 2). Like the parent compound, thioflavin-T (Klunk et al., 2001), BTA-1 stained plaques, cerebrovascular amyloid, and NFTs at these relatively high concentrations. BTA-1 appeared to stain plaques and cerebrovascular amyloid more intensely than it stained NFTs. Very little background staining was observed. Most of the background fluorescence seen in Figure 2 was caused by residual lipofuscin autofluorescence (distinguished by the fact that it is visible in all filter sets). Equivalent results were observed in frozen sec- 
tions. Essentially no staining was observed in control brain, which had been shown to contain no plaques or NFTs by the standard CERAD neuropathology protocol (Mirra et al., 1991) (data not shown).

The tissue staining results supported the specificity of BTA- 1 for $\beta$-sheet deposits in a qualitative manner, but the 100 nM BTA-1 concentration used for staining was not representative of the low or subnanomolar concentrations achieved by typical PET ligands in vivo. In addition, it is possible that the fluorescence properties of BTA-1 change after binding to amyloid
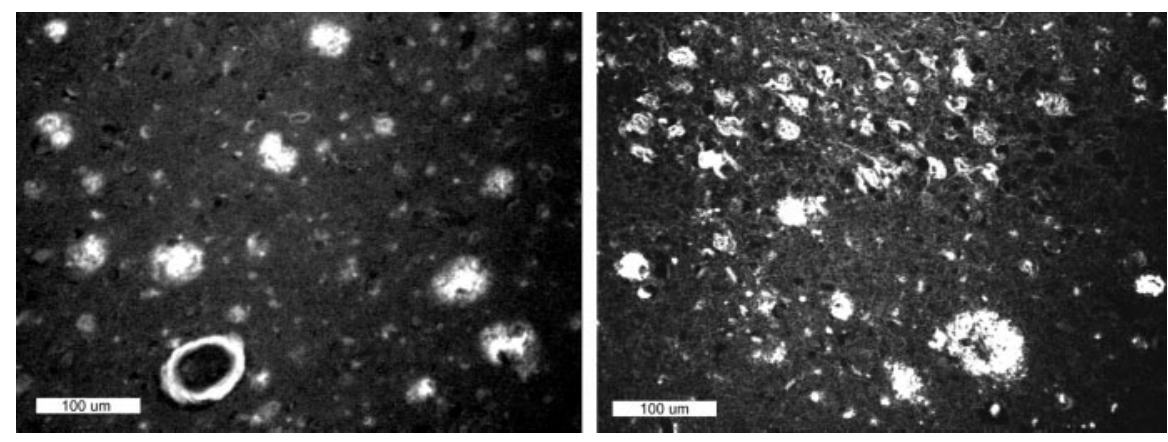

Figure 2. Paraffin sections $(8 \mu \mathrm{m})$ from AD brain stained with $100 \mathrm{~nm}$ BTA-1. Left panel shows plaques and cerebrovascular amyloid in the frontal cortex. Right panel shows plaques and neurofibrillary tangles in the entorhinal cortex. Scale bar, $100 \mu \mathrm{m}$. Most smaller bright spots are residual lipofuscin autofluorescence.
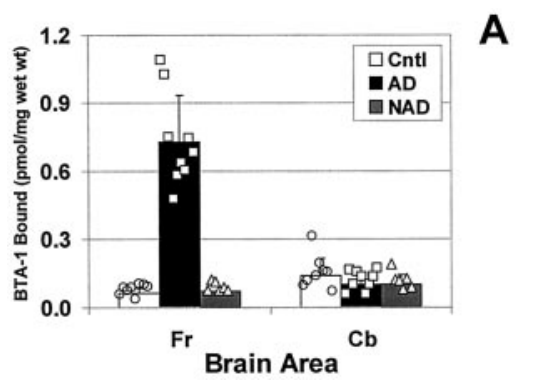

Figure 3. A, Comparison of $\left[{ }^{3} \mathrm{H}\right] \mathrm{BTA}-1$ binding to homogenates from control (open bars, circles), AD ( filled bars, squares), and NAD brain (hatched bars, triangles) frontal gray (Fr) or cerebellum ( $C b)$. B, Ratio of $\left[{ }^{3} \mathrm{H}\right] \mathrm{BTA}-1$ binding to the $\mathrm{Fr}$ and $\mathrm{Cb}$ for each individual brain. Bars represent the mean, and error bars represent the SD. Also shown are the individual data points.

in a way that enhances the fluorescence similar to that observed for thioflavin-T (LeVine, 1993). This could make the staining appear more specific than it actually was. Therefore, quantitative binding studies were performed in tissue homogenates using 1.2 nм $\left[{ }^{3} \mathrm{H}\right]$ BTA- 1 .

$\left[{ }^{3} \mathrm{H}\right] \mathrm{BTA}-1$ binding was linear with tissue concentration $(r=$ $0.993)$ and $\left[{ }^{3} \mathrm{H}\right] \mathrm{BTA}-1$ concentration $(r=0.999)$ throughout the range used in this study. In homogenates from frontal gray, significantly more $\left[{ }^{3} \mathrm{H}\right] \mathrm{BTA}-1$ was bound to amyloid-containing $\mathrm{AD}$ brain than to the control or NAD brains, which lacked observable amyloid deposits $(p<0.0002)$ (Fig. 3). Using $1.2 \mathrm{~nm}$ $\left[{ }^{3} \mathrm{H}\right] \mathrm{BTA}-1$, the average amount of $\left[{ }^{3} \mathrm{H}\right] \mathrm{BTA}-1$ bound to AD frontal gray $(0.73 \pm 0.21 \mathrm{pmol} / \mathrm{mg}$ wet weight $)$ was $>10$-fold higher than that bound to frontal gray obtained from either control brain $(0.061 \pm 0.023 \mathrm{pmol} / \mathrm{mg}$ wet weight $)$ or NAD brain $(0.072 \pm 0.021 \mathrm{pmol} / \mathrm{mg}$ wet weight $)$.

As expected, and confirming the specificity of BTA-1, a very different finding was observed in the cerebellum where fibrillar (i.e., Congo red or thioflavin-S positive) amyloid deposits are very rarely observed (Joachim et al., 1989; Yamaguchi et al., 1989; Mann et al., 1996) (Fig. 3A). Binding was low in the cerebellar homogenates of all three groups, and there was complete overlap between binding to $\mathrm{AD}$ cerebellum and binding to cerebellum from control and NAD brains.

The lack of difference in $\left[{ }^{3} \mathrm{H}\right]$ BTA-1 binding in cerebellum is important because it identifies this brain area as a potential reference tissue that could be used to simplify the quantitation of future PET studies. To more precisely examine this issue, ratios of $\left[{ }^{3} \mathrm{H}\right] \mathrm{BTA}-1$ binding to frontal gray and cerebellum were determined for each individual brain studied, and the data were expressed as the frontal/cerebellar ratio for each brain (Fig. 3B).

When expressed in this manner, the clear differentiation between amyloid-containing $\mathrm{AD}$ brain and the nonamyloid-containing control groups remained. The ratio in $\mathrm{AD}$ brain $(7.8 \pm 4.0)$ was $>10$-fold higher than the ratio calculated in either control brain $(0.59 \pm 0.40 ; p<0.0006)$ or NAD brain $(0.78 \pm 0.26 ; p<$ 0.0007).

Approximately $94 \%$ of $\left[{ }^{3} \mathrm{H}\right] \mathrm{BTA}-1$ binding to homogenates of AD frontal gray was displaceable by $3 \mu \mathrm{M}$ unlabeled BTA-1 (i.e., is specific). Specific binding represented only $36-52 \%$ of binding in all samples except $\mathrm{AD}$ frontal gray. The absolute value of nonspecific binding was not significantly different in the frontal gray or cerebellum of any of the groups studied, although it was lowest in $\mathrm{AD}$ frontal gray.

Detailed Scatchard analysis of $\left[{ }^{3} \mathrm{H}\right]$ BTA-1 binding to homogenates of frontal gray from three $\mathrm{AD}$ and three control brains showed high-affinity binding to be present only in AD frontal gray. $\left[{ }^{3} \mathrm{H}\right] \mathrm{BTA}-1$ appeared to bind to a single, high-affinity binding site in $\mathrm{AD}$ frontal gray with a mean $K_{\mathrm{d}}$ of $5.8 \pm 0.90 \mathrm{~nm}$ and a mean $B_{\max }$ of $5.4 \pm 1.1 \mathrm{pmol} / \mathrm{mg}$ wet weight. (Fig. 4 ). This affinity was very similar to the high-affinity binding of $\left[{ }^{3} \mathrm{H}\right] \mathrm{BTA}-1$ to

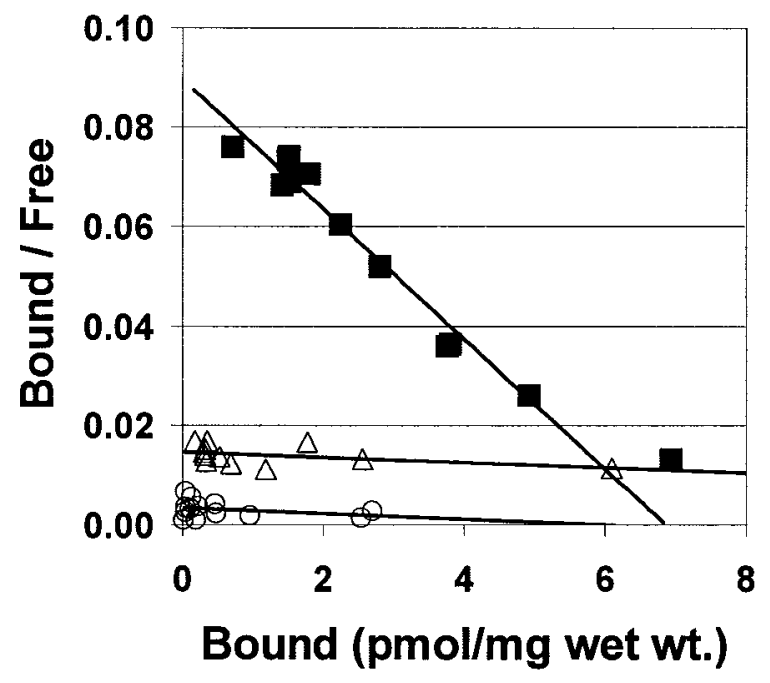

Figure 4. Scatchard plots showing the binding of $\left[{ }^{3} \mathrm{H}\right] \mathrm{BTA}-1$ to homogenates from $A D$ frontal gray matter $(\square)$ and underlying frontal white matter from the same $A D$ brain $(\triangle)$. In this $A D$ frontal gray matter homogenate, the $K_{\mathrm{d}}$ was $4.4 \mathrm{~nm}$ and the $B_{\max }$ was $6.9 \mathrm{pmol} / \mathrm{mg}$ wet weight. In the frontal white matter immediately underlying this gray matter sample, the $K_{\mathrm{d}}$ was $111 \mathrm{~nm}$ and the $B_{\max }$ was $27 \mathrm{pmol} / \mathrm{mg}$ wet weight. Also shown is a Scatchard plot showing the binding of [ ${ }^{3} \mathrm{H}$ ]BTA-1 to a homogenate from control brain frontal gray $(O)$ in which the $K_{d}$ was $180 \mathrm{~nm}$ and the $B_{\max }$ was $5.9 \mathrm{pmol} / \mathrm{mg}$ wet weight. 
Table 1. Demographic and neuropathological characteristics

\begin{tabular}{|c|c|c|c|c|c|c|}
\hline Brain no. & $\begin{array}{l}\text { Primary neuropath } \\
\text { Dx }\end{array}$ & Other neuropath Dx & $\begin{array}{l}\text { Braak } \\
\text { stage }\end{array}$ & Cortical NPa & Age & $\begin{array}{l}\text { PMl } \\
(\mathrm{hr})\end{array}$ \\
\hline AD 01 & $A D^{a}$ & AA (severe) & $\mathrm{VI}$ & Frequent & 83 & 3 \\
\hline AD 02 & $A D^{a}$ & $\mathrm{AA}$ (severe) & $\mathrm{VI}$ & Frequent & 57 & 4 \\
\hline AD 03 & $A D^{a}$ & $A A($ mild $)$ & $\mathrm{VI}$ & Frequent & 78 & 3 \\
\hline AD 04 & $A D^{a}$ & $\mathrm{AA}$ (mild), DLB $(1 / 10)^{b}$ & $\mathrm{VI}$ & Frequent & 80 & 4 \\
\hline AD 05 & $A D^{a}$ & $\mathrm{AA}$ (moderate) & VI & Frequent & 78 & 9 \\
\hline AD 06 & $A D^{a}$ & Chronic subdural hematoma & IV & Frequent & 85 & 3 \\
\hline AD 07 & $A D^{a}$ & AA (severe), old infarct right putamen & $\mathrm{VI}$ & Frequent & 79 & 4 \\
\hline AD 08 & $\mathrm{AD}^{a}$ & AA (mild), old infarct left basis pontis & IV & Frequent & 83 & 4 \\
\hline \multirow[t]{2}{*}{ AD 09} & $\mathrm{AD}^{a}$ & $\begin{array}{l}\text { Infarcts, right putamen ( } 3 \text { old); } \\
\text { Left thalamus ( } 1 \text { subacute) }\end{array}$ & IV & Frequent & 84 & 4 \\
\hline & & & & $\begin{array}{l}\text { Average: } \\
\text { SD }\end{array}$ & $\begin{array}{r}78.6 \\
8.5\end{array}$ & $\begin{array}{l}4.2 \\
1.9\end{array}$ \\
\hline Cntl 01 & Normal brain ${ }^{a}$ & Moderate atherosclerosis, circle of Willis & 0 & None & 72 & 18 \\
\hline Cnt1 02 & Normal brain ${ }^{a}$ & $\begin{array}{l}\text { Persistent posterior fetal circulation, bilaterally } \\
\text { Incidental choroid plexus cyst }\end{array}$ & 1 & None & 82 & 4 \\
\hline Cnt1 03 & Normal brain ${ }^{a}$ & Moderate congestion of leptomeninges & 0 & None & 75 & 8 \\
\hline Cntl 04 & Normal brain ${ }^{a}$ & Incidental focal hypoplasia of corpus callosum & $\|$ & None & 82 & 3 \\
\hline Cnt1 05 & Normal brain ${ }^{a}$ & None & I & None & 74 & 5 \\
\hline Cntl 06 & Normal brain ${ }^{a}$ & $\begin{array}{l}\text { Atherosclerosis, circle of Willis } \\
\text { Old infarcts cerebellar cortex, inferior olivary nucleus }\end{array}$ & $\|$ & Rare & 72 & 4 \\
\hline Cnt1 07 & Normal brain ${ }^{a}$ & Subacute infarct right brainstem & I & None & 74 & 6 \\
\hline \multirow[t]{2}{*}{ Cnt1 08} & Normal brain ${ }^{a}$ & None & 0 & None & 53 & 5 \\
\hline & & & & $\begin{array}{l}\text { Average: } \\
\text { SD } \\
p=(\text { vs AD) }\end{array}$ & $\begin{array}{r}73.0 \\
9.0 \\
0.21\end{array}$ & $\begin{array}{r}6.6 \\
4.8 \\
0.22\end{array}$ \\
\hline NAD 01 & Pure $\mathrm{DLB}(7 / 10)^{b}$ & None & I & None & 69 & 10 \\
\hline NAD 02 & Huntington's & $\begin{array}{l}\text { Status post evacuation subdural hematoma, } \\
\text { Atherosclerosis, circle of Willis }\end{array}$ & I & None & 64 & 7 \\
\hline NAD 03 & Pick's & Atherosclerosis, circle of Willis & 0 & None & 66 & 4 \\
\hline NAD 04 & $\begin{array}{l}\text { MND-inclusion } \\
\text { Dementia }\end{array}$ & Severe cortical atrophy, atherosclerosis, circle of Willis & 0 & None & 75 & 8 \\
\hline NAD 05 & DLDHF & Mesial temporal sclerosis & I & None & 56 & 4 \\
\hline \multirow[t]{4}{*}{ NAD 06} & $\operatorname{DLB}(6 / 10)^{b}$ & Parkinson's disease & I & None & 87 & 8 \\
\hline & & & & Average: & 69.5 & 6.8 \\
\hline & & & & SD & 10.6 & 2.4 \\
\hline & & & & $p=($ vs AD) & 0.11 & 0.05 \\
\hline
\end{tabular}

NP, Neuritic plaques; PMI, postmortem interval; AD, Alzheimer's disease; AA, amyloid angiopathy; DLB, dementia with Lewy Bodies; SD, standard deviation; $p=$ (vs AD), $p$ values compared with corresponding values for AD cases; $(\mathrm{ntl}$, control; NAD, demented, non-Alzheimer's disease; MND, motor neuron disease-inclusion dementia (Jackson et al., 1996); DLDHF, dementia lacking distinctive histologic features (Mann, 1998); neuropath; Dx, neuropathological diagnosis. ${ }^{a}$ CERAD criteria (Mirra et al., 1991).

${ }^{b}$ Scored according to consensus criteria (McKeith et al., 1996).

synthetic $\mathrm{A} \beta(1-40)$ or $\mathrm{A} \beta(1-42)$ fibrils $\left(K_{\mathrm{d}}=2.8 \pm 0.35 \mathrm{nM}\right.$; data not shown).

Control brains showed only low-affinity binding, having a mean $K_{\mathrm{d}}$ of $132 \pm 59 \mathrm{~nm}$ and a mean $B_{\max }$ of $11.3 \pm 5.2 \mathrm{pmol} / \mathrm{mg}$ wet weight (Fig. 4). The frontal gray matter samples used in this study were dissected to remove the underlying white matter as much as possible. Comparing the frontal gray matter from an $\mathrm{AD}$ brain with the white matter immediately underlying it showed a marked difference in high-affinity $\left[{ }^{3} \mathrm{H}\right] \mathrm{BTA}-1$ binding. Figure 4 includes a Scatchard analysis of the binding of $\left[{ }^{3} \mathrm{H}\right] \mathrm{BTA}-1$ to the white matter dissected from directly beneath the gray matter of the $\mathrm{AD}$ brain also shown in Figure 4. In contrast to the frontal gray matter, the frontal white matter showed only a low-affinity binding component, similar to that seen in control brain frontal gray. This low-affinity binding component in control frontal gray and $\mathrm{AD}$ frontal white matter would not play a significant role in in vivo imaging studies using high specific-activity radiotracers present at low nanomolar concentrations.

To address the relative contributions of $\left[{ }^{3} \mathrm{H}\right] \mathrm{BTA}-1$ binding to $\mathrm{A} \beta$ and tau deposits in the frontal gray of $\mathrm{AD}$ brain we com- pared $\left[{ }^{3} \mathrm{H}\right] \mathrm{BTA}-1$ binding in homogenates from entorhinal cortex, frontal gray, and cerebellum from a typical Braak stage VI AD brain (Table 1, AD 01) and a Braak stage II control brain (Table 1, Cntl 04), matched for age and postmortem interval. This control brain had frequent NFTs in the entorhinal cortex (Fig. 5A), similar in numbers to those found in many AD cases (Fig. $5 B$ ); however, it had no neuritic or diffuse plaques in any area of the brain (Fig. $5 A, C, E$ ). $\left[{ }^{3} \mathrm{H}\right] \mathrm{BTA}-1$ binding in the plaque-free and NFTrich EC region of this Cntl 04 brain was no greater than $\left[{ }^{3} \mathrm{H}\right] \mathrm{BTA}-1$ binding in the plaque- and NFT-free cerebellum and frontal gray from this brain (Table 2). A similar survey of these same brain areas in a Braak VI AD brain (Table 2) showed low binding in NFT-free cerebellum and NFT-rich EC and $>10$-fold higher levels in frontal gray, where there are frequent numbers of neuritic plaques (Fig. 5D). The extensive NFT pathology in the EC of the Cntl 04 and AD 01 brains, coupled with the low $\left[{ }^{3} \mathrm{H}\right] \mathrm{BTA}-1$ binding in the EC, suggests that at low nanomolar concentrations the amount of $\left[{ }^{3} \mathrm{H}\right] \mathrm{BTA}-1$ binding to NFT deposits is very small in comparison with the amount of $\left[{ }^{3} \mathrm{H}\right] \mathrm{BTA}-1$ bound to $\mathrm{A} \beta$ in the plaques and cerebrovascular amyloid of $\mathrm{AD}$ 

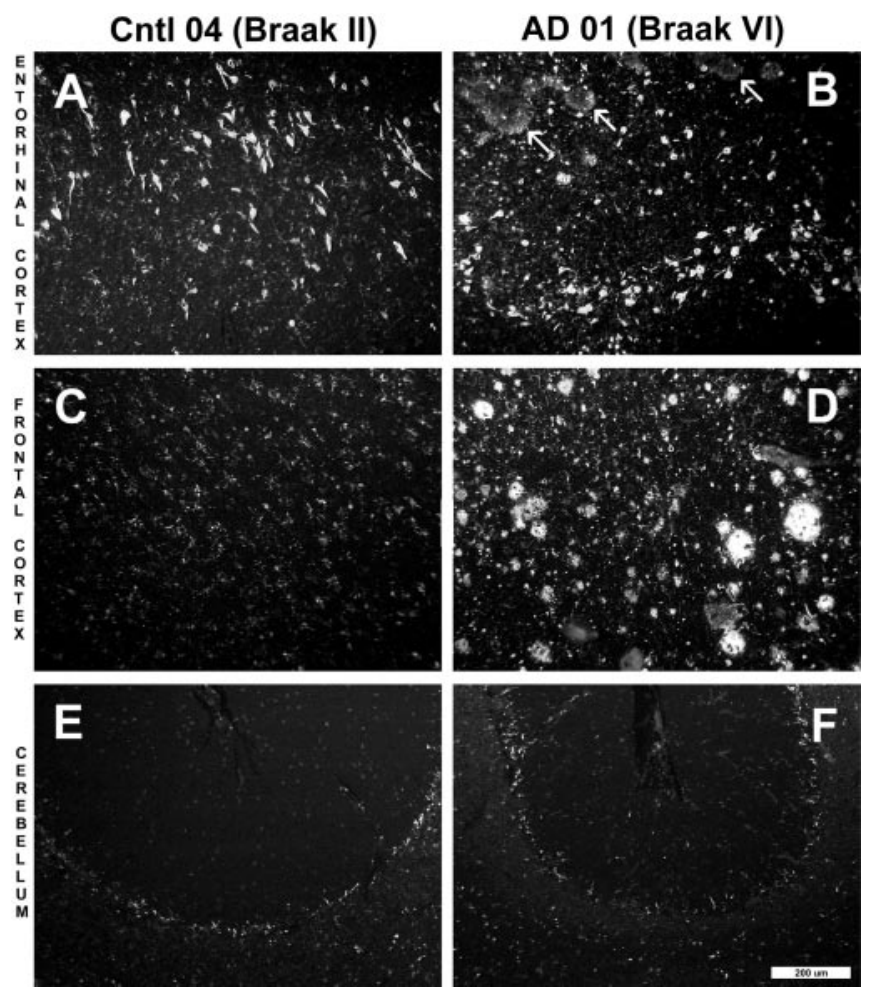

Figure 5. Paraffin sections $(8 \mu \mathrm{m})$ from the entorhinal cortex $(A, B)$, frontal cortex $(C, D)$, and cerebellum $(E, F)$ of a Braak stage II control brain $(A, C, E,(n t)$ O4) and a Braak stage VI AD brain $(B, D, F, A D 01)$ stained with $X-34 . X-34$ is a highly sensitive, fluorescent Congo red derivative that intensely stains plaques, NFTs, and amyloid deposits in general (Styren et al., 2000). Marked atrophy of $A D$ tissue was notable in all regions. In the entorhinal cortex of the control subject $(A)$, frequent numbers of NFTs were seen, whereas there were no amyloid deposits. In the $A D$ case $(B)$, there also were frequent NFTs along with diffuse amyloid deposits (arrows). $X$-34-positive NFTs and amyloid plaques were absent from the frontal cortex of the control case $(C$, whereas they were abundant in $A D(D)$. There was no detectableX-34 staining of plaques or $\mathrm{NFT}$ in control $(E)$ and $\mathrm{AD}(F)$ cerebellum. Control frontal cortex $(C)$ and cerebellum from both control and $\operatorname{AD}(E, F)$ show small stellate cells that stain with X-34. Scale bar, $200 \mu \mathrm{m}$.

Table 2. [ $\left.{ }^{3} \mathrm{H}\right] \mathrm{BTA}-1$ binding to specified areas of a Braak stage II control brain (Cntl 04) and a Braak stage VI AD brain (AD 01)

\begin{tabular}{llll}
\hline $\begin{array}{l}\text { Brain } \\
\text { area }\end{array}$ & \multicolumn{2}{l}{ pmol BTA-1/mg wet weight (mean \pm SD) } & \\
\cline { 2 - 3 } & Cntl 04 & AD 01 & $p$ value \\
\hline EC & $0.078 \pm 0.006$ & $0.082 \pm 0.008$ & 0.489 \\
$\mathrm{Fr}$ & $0.093 \pm 0.004$ & $0.887 \pm 0.011$ & 0.00001 \\
$\mathrm{Cb}$ & $0.078 \pm 0.0001$ & $0.043 \pm 0.004$ & 0.005 \\
\hline
\end{tabular}

See Table 1 for details. EC, Entorhinal cortex; Fr, frontal cortex; Cb, cerebellum.

aStudent's t test comparison of control and AD values.

frontal gray. The AD 01 brain showed diffuse amyloid plaque deposits in the EC (Fig. $5 B$ ), which also did not appear to produce significant $\left[{ }^{3} \mathrm{H}\right] \mathrm{BTA}-1$ binding. The frontal cortex had extensive amyloid plaques that were both compact and diffuse and associated with high levels of $\left[{ }^{3} \mathrm{H}\right]$ BTA-1 binding (Fig. $5 D$, Table 2). The qualitative BTA-1 staining of NFTs, seen at $100 \mathrm{~nm}$ concentrations (Fig. 2), is apparently not reflected by significant amounts of $\left[{ }^{3} \mathrm{H}\right]$ BTA-1 binding at a concentration of $1.2 \mathrm{nM}$.

As further evidence that $\left[{ }^{3} \mathrm{H}\right] \mathrm{BTA}-1$ binding to brain homogenates was dominated by the $\mathrm{A} \beta$ component, we compared the binding of 10 structurally related BTA derivatives to synthetic $\mathrm{A} \beta(1-40)$ fibrils and to $\mathrm{AD}$ brain frontal gray. To get a broad range of affinities for the correlation, we chose compounds with $K_{\mathrm{i}}$ values for inhibition of $\left[{ }^{3} \mathrm{H}\right] \mathrm{BTA}-1$ binding to $\mathrm{A} \beta(1-40)$

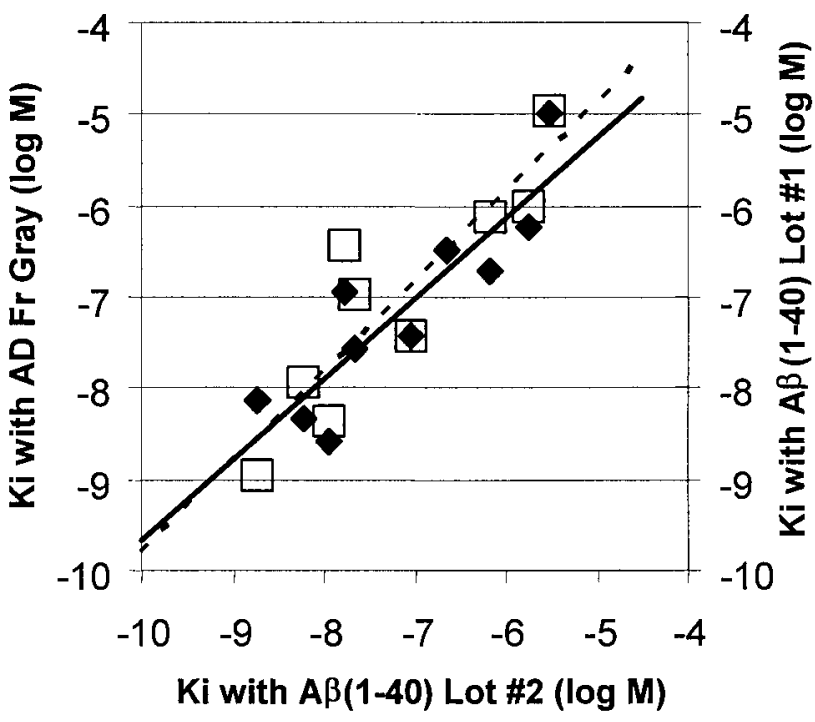

Figure 6. Comparison of the $K_{\mathrm{i}}$ values of 10 BTA-1 derivatives for inhibition of $\left[{ }^{3} \mathrm{H}\right] \mathrm{BTA}-1$ binding to $A \beta(1-40)$ fibrils and homogenates of $A D$ frontal gray ( filled diamonds, solid line). Also shown is a comparison of the same data for $A \beta(1-40)$ fibrils compared with $K_{\mathrm{i}}$ values previously determined in a separate, older lot of $A \beta(1-40)$ fibrils (open squares, dashed line).

fibrils ranging from 1.8 to $3030 \mathrm{~nm}$. A good correlation was found between the $K_{\mathrm{i}}$ values determined for [ $\left.{ }^{3} \mathrm{H}\right] \mathrm{BTA}-1$ binding to synthetic $\mathrm{A} \beta(1-40)$ fibrils and to the $\mathrm{AD}$ brain homogenate (Fig. 6). In fact, the correlation between $K_{\mathrm{i}}$ values determined in $\mathrm{AD}$ brain and synthetic $\mathrm{A} \beta$ binding assays $(r=0.88)$ was no worse than the correlation of $K_{\mathrm{i}}$ values determined with two separately aggregated lots of synthetic $\mathrm{A} \beta(1-40)(r=0.89)$ (Fig. 6). This finding suggested that the $\left[{ }^{3} \mathrm{H}\right] \mathrm{BTA}-1$ binding site in AD brain homogenates had the same structure-affinity relationship as the binding site in suspensions of pure, synthetic $A \beta(1-40)$ fibrils and was consistent with the hypothesis that $\left[{ }^{3} \mathrm{H}\right] \mathrm{BTA}-1$ binding to $\mathrm{AD}$ brain homogenates was dominated by binding to fibrillar $A \beta$ deposits.

Additional experiments were performed using the resources of the NIMH Psychoactive Drug Screening Program to assess whether BTA-1 interacts with any of a representative array of neurotransmitter receptors and transporters (Rothman et al., 2000; Roth et al., 2001). The array has been published previously (Roth et al., 2001) and includes adrenergic, serotonergic, muscarininc, dopaminergic, opiate, vasopressin, oxytocin, GABA, glutamate, and imidazoline receptor sites. Using $10 \mu \mathrm{M}$ BTA-1, no inhibition was observed at any receptor site except at the norepinephrine transporter, where the $K_{\mathrm{i}}$ of BTA- 1 was $4504 \pm 31 \mathrm{~nm}$, a value 1000 -fold higher than the $K_{\mathrm{d}}$ for $\mathrm{A} \beta(1-40)$ or $\mathrm{AD}$ brain.

\section{Discussion}

Although a previous study showed good pharmacokinetic properties for BTA-1 in normal mice (Mathis et al., 2002), it remained to be shown that BTA-1 could specifically bind to its amyloid target in human brain and to more precisely characterize that target in the complex milieu of human AD brain. The ability of BTA-1 to fluorescently stain amyloid deposits in postmortem tissue sections gives some indication that this compound would specifically bind amyloid deposits. However, this staining is a qualitative technique and certainly does not prove sufficient specificity for use as an in vivo PET amyloid-imaging agent in humans. In an effort to address this question, we quantitatively examined the binding of $\left[{ }^{3} \mathrm{H}\right] \mathrm{BTA}-1$ to homogenates of post- 
mortem human brain at concentrations typical of in vivo PET radiotracer studies. We found that 12 -fold more $\left[{ }^{3} \mathrm{H}\right] \mathrm{BTA}-1$ bound to homogenates from $\mathrm{AD}$ brain frontal gray than to similar homogenates from control and NAD brain. There was no overlap between the AD group and the other groups. Binding of $\left[{ }^{3} \mathrm{H}\right] \mathrm{BTA}-1$ to cerebellar homogenates was identical in all three groups, making cerebellum a good candidate for a reference tissue for PET studies. More than $90 \%$ of $\left[{ }^{3} \mathrm{H}\right] \mathrm{BTA}-1$ binding to AD frontal gray was specific. The affinity of $\left[{ }^{3} \mathrm{H}\right] \mathrm{BTA}-1$ binding to $\mathrm{AD}$ frontal gray was relatively high $(\sim 6 \mathrm{nM})$ and very similar to the affinity of $\left[{ }^{3} \mathrm{H}\right] \mathrm{BTA}-1$ for synthetic $\mathrm{A} \beta$ fibrils $(\sim 3 \mathrm{nM})$. Control brain frontal gray and frontal white matter from $\mathrm{AD}$ showed essentially no high-affinity binding. NFTs alone did not appear to increase $\left[{ }^{3} \mathrm{H}\right]$ BTA-1 binding above control levels, suggesting that most of the $\left[{ }^{3} \mathrm{H}\right] \mathrm{BTA}-1$ binding represents an interaction with $\mathrm{A} \beta$ deposits. Consistent with this, for a series of 10 BTA-1 derivatives having a 1000-fold range of affinity for binding amyloid, the $K_{\mathrm{i}}$ values for the inhibition of [ ${ }^{3} \mathrm{H}$ ]BTA- 1 binding to $\mathrm{A} \beta(1-$ 40) fibrils correlated very well with their $K_{\mathrm{i}}$ values for inhibition of [ $\left.{ }^{3} \mathrm{H}\right]$ BTA- 1 binding to AD brain homogenates. BTA-1 did not bind significantly to a wide array of neurotransmitter receptors or transporters. All of these data are consistent with the notion that $\left[{ }^{3} \mathrm{H}\right] \mathrm{BTA}-1$ binding in AD brain is mainly accounted for by binding to fibrillar $\mathrm{A} \beta$.

Although [ $\left.{ }^{3} \mathrm{H}\right]$ BTA-1 binding clearly distinguished AD brain homogenates from the control and NAD groups, it is important to note that the goal of this study was not to test whether we could use $\left[{ }^{3} \mathrm{H}\right] \mathrm{BTA}-1$ to establish a diagnosis. The validation of BTA-1, or any other compound, as an accurate tool to quantify amyloid is a complex process composed of many steps such as the one described in this study. In addition, it should be recognized that the frontal cortex does not represent the area of maximal pathologic change for several of the diseases included in the NAD group, and one would need to examine other brain areas to adequately address diagnostic issues in these cases.

The purpose of this study was solely to determine whether the binding of $\left[{ }^{3} \mathrm{H}\right] \mathrm{BTA}-1$ to areas of human brain with abundant amyloid deposits (e.g., AD frontal gray) was dominated by a specific interaction with the amyloid deposits. It was possible that $\left[{ }^{3} \mathrm{H}\right] \mathrm{BTA}-1$ could have nonspecific interactions with binding sites on non-amyloid components in brain that would be of sufficient magnitude to mask the specific, amyloid binding observed in $\mathrm{AD}$ brain. Therefore, both control groups were chosen for the absence of visible $A \beta$ deposits to assess the contribution of the non-amyloid components in isolation. The NAD group was included to control for the possibility that $\left[{ }^{3} \mathrm{H}\right] \mathrm{BTA}-1$ binding was affected by general neurodegenerative processes in a manner unrelated to amyloid deposition. Likewise, it is possible that highly lipophilic brain areas such as white matter from both $\mathrm{AD}$ and control brains could have large amounts of nonspecific, lipophilic interactions with $\left[{ }^{3} \mathrm{H}\right]$ BTA-1 that would overshadow the specific, amyloid binding in the overlying cortex. Our results indicated that high-affinity $\left[{ }^{3} \mathrm{H}\right] \mathrm{BTA}-1$ binding was much greater in $\mathrm{AD}$ frontal gray than either control frontal gray or $\mathrm{AD}$ frontal white matter and suggested that the binding of $\left[{ }^{3} \mathrm{H}\right] \mathrm{BTA}-$ 1 to $\mathrm{AD}$ brain mainly represented a specific interaction with $\mathrm{A} \beta$ deposits.

Taken together with the previously reported pharmacokinetic properties of $\left[{ }^{11} \mathrm{C}\right] \mathrm{BTA}-1$ in mice and successful in vivo imaging of plaques in transgenic mice using BTA-1 and multiphoton microscopy (Mathis et al., 2002), the findings of the present study suggest that BTA-1 is a good candidate as an in vivo PET amyloidimaging agent. Further, detailed, quantitative validation studies in transgenic mice will need to be performed to confirm the potential of BTA-1. In addition, pharmacokinetic studies are underway in primate brain to verify the mouse studies. Promising results from all of these studies and an acceptable toxicological profile will justify preliminary studies in human subjects with and without AD.

\section{References}

Bard F, Cannon C, Barbour R, Burke RL, Games D, Grajeda H, Guido T, Hu K, Huang J, Johnson-Wood K, Kholodenko D, Lee M, Lieberburg I, Motter R, Nguyen M, Soriano F, Vasquez N, Weiss K, Welch B, Schenk D, Yednock T (2000) Peripherally administered antibodies against amyloid $\beta$-peptide enter the central nervous system and reduce pathology in a mouse model of Alzheimer disease. Nat Med 6:916-919.

Bennett JP, Yamamura HI (1985) Neurotransmitter, hormone, or drug receptor binding methods. In: Neurotransmitter receptor binding (Yamamura HI, Enna SJ, Kuhar MJ, eds), pp 61-89. New York: Raven.

DeMattos RB, Bales KR, Cummins DJ, Dodart JC, Paul SM, Holtzman DM (2001) Peripheral anti-A beta antibody alters CNS and plasma A beta clearance and decreases brain A beta burden in a mouse model of Alzheimer's disease. Proc Natl Acad Sci USA 98:8850-8855.

Goate A, Chartier-Harlin MC, Mullan M, Brown J, Crawford F, Fidani L, Giuffra L, Haynes A, Irving N, James L, Mant R, Newton P, Rooke K, Roques P, Talbot C, Pericak-Vance M, Roses A, Williamson R, Rossor M, Owen M, Hardy J (1991) Segregation of a missense mutation in the amyloid precursor protein gene with familial Alzheimer's disease. Nature 349:704-706

Goedert M, Spillantini MG (2000) Tau mutations in frontotemporal dementia FTDP-17 and their relevance for Alzheimer's disease. Biochim Biophys Acta 1502:110-121.

Golde TE, Eckman CB, Younkin SG (2000) Biochemical detection of Abeta isoforms: implications for pathogenesis, diagnosis, and treatment of Alzheimer's disease. Biochim Biophys Acta 1502:172-187.

Hardy J (1992) An "anatomical cascade hypothesis" for Alzheimer's disease. Trends Neurosci 15:200-201.

Hardy J, Allsop D (1991) Amyloid deposition as the central event in the aetiology of Alzheimer's disease. Trends Pharmacol Sci 12:383-388.

Hardy J, Duff K, Hardy KG, Perez-Tur J, Hutton M (1998) Genetic dissection of Alzheimer's disease and related dementias: amyloid and its relationship to tau. Nat Neurosci 1:355-358.

Jackson M, Lennox G, Lowe J (1996) Motor neurone disease-inclusion dementia. Neurodegeneration 5:339-350.

Joachim CL, Morris JH, Selkoe DJ (1989) Diffuse senile plaques occur commonly in the cerebellum in Alzheimer's disease. Am J Pathol 135:309-319.

Kirschner DA, Abraham C, Selkoe DJ (1986) X-ray diffraction from intraneuronal paired helical filaments and extraneuronal amyloid fibers in Alzheimer disease indicates cross-beta conformation. Proc Natl Acad Sci USA 83:503-507.

Klunk WE (1998) Biological markers of Alzheimer's disease. Neurobiol Aging 19:145-147.

Klunk WE, Debnath ML, Pettegrew JW (1994) Development of small molecule probes for the beta-amyloid protein of Alzheimer's disease. Neurobiol Aging 15:691-698.

Klunk WE, Wang Y, Huang G-F, Debnath ML, Holt DP, Mathis CA (2001) Uncharged thioflavin-T derivatives bind to amyloid-beta protein with high affinity and readily enter the brain. Life Sci 69:1471-1484.

LeVine H (1993) Thioflavine T interaction with synthetic Alzheimer's disease beta-amyloid peptides: detection of amyloid aggregation in solution. Protein Sci 2:404-410.

Lopez OL, Becker JT, Klunk WE, Saxton J, Hamilton RL, Kaufer DI, Sweet RA, Cidis-Meltzer C, Wisniewski S, Kamboh MI, DeKosky ST (2000) Research evaluation and diagnosis of probable Alzheimer's disease over the last two decades. I. Neurology 55:1854-1862.

Mann DM (1998) Dementia of frontal type and dementias with subcortical gliosis. Brain Pathol 8:325-338.

Mann DM, Iwatsubo T, Snowden JS (1996) Atypical amyloid (A beta) deposition in the cerebellum in Alzheimer's disease: an immunohistochemical study using end-specific A beta monoclonal antibodies. Acta Neuropathol 91:647-653.

Mathis CA, Bacskai BJ, Kajdasz ST, Mclellan ME, Frosch MP, Hyman BT, Holt DP, Wang Y, Huang G-F, Debnath ML, Klunk WE (2002) A li- 
pophilic thioflavin-T derivative for positron emission tomography (PET) imaging of amyloid in brain. Bioorg Med Chem Lett 12:295-298.

McKeith IG, Galasko D, Kosaka K, Perry EK, Dickson DW, Hansen LA, Salmon DP, Lowe J, Mirra SS, Byrne EJ, Lennox G, Quinn NP, Edwardson JA, Ince PG, Bergeron C, Burns A, Miller BL, Lovestone S, Collerton D, Jansen EN, Ballard C, de Vos RA, Wilcock GK, Jellinger KA, Perry RH (1996) Consensus guidelines for the clinical and pathologic diagnosis of dementia with Lewy bodies (DLB): report of the consortium on DLB international workshop. Neurology 47:1113-1124.

Mirra SS, Heyman A, McKeel D, Sumi SM, Crain BJ, Brownlee LM, Vogel FS, Hughes JP, van Belle G, Berg L (1991) The consortium to establish a registry for Alzheimer's disease (CERAD). Part II. Standardization of the neuropathologic assessment of Alzheimer's disease. Neurology 41:479-486.

Mullan M, Crawford F, Axelman K, Houlden H, Lilius L, Winblad B, Lannfelt L (1992) A pathogenic mutation for probable Alzheimer's disease in the APP gene at the N-terminus of beta-amyloid. Nat Genet 1:345-347.

Olson RE, Copeland RA, Seiffert D (2001) Progress towards testing the amyloid hypothesis: inhibitors of APP processing. Curr Opin Drug Discov Devel 4:390-401.

Roth BL, Ernsberger P, Steinberg SA, Rao S, Rauser L, Savage J, Hufeisen S, Berridge MS, Muzic RF Jr (2001) The in vitro pharmacology of the beta- adrenergic receptor pet ligand (s)-fluorocarazolol reveals high affinity for cloned beta-adrenergic receptors and moderate affinity for the human 5-HT1A receptor. Psychopharmacology 157:111-114.

Rothman RB, Baumann MH, Savage JE, Rauser L, McBride A, Hufeisen SJ, Roth BL (2000) Evidence for possible involvement of 5-HT(2B) receptors in the cardiac valvulopathy associated with fenfluramine and other serotonergic medications. Circulation 102:2836-2841.

Schenk D, Barbour R, Dunn W, Gordon G, Grajeda H, Guido T, Hu K, Huang J, Johnson-Wood K, Khan K, Kholodenko D, Lee M, Liao Z, Lieberburg I, Motter R, Mutter L, Soriano F, Shopp G, Vasquez N, Vandevert C, Walker S, Wogulis M, Yednock T, Games D, Seubert P (1999) Immunization with amyloid-beta attenuates Alzheimer-disease-like pathology in the PDAPP mouse. Nature 400:173-177.

Styren SD, Hamilton RL, Styren GC, Klunk WE (2000) X-34, a fluorescent derivative of Congo red: a novel histochemical stain for Alzheimer's disease pathology. J Histochem Cytochem 48:1223-1232.

Yamaguchi H, Hirai S, Morimatsu M, Shoji M, Nakazato Y (1989) Diffuse type of senile plaques in the cerebellum of Alzheimer-type dementia demonstrated by beta protein immunostain. Acta Neuropathol 77:314-319. 